\author{
Paulina Pietrzak ${ }^{1}$, Anna A. Białek-Jaworska ${ }^{1}$, Arkadiusz Bernal' \\ Anna Leszczyłowska ${ }^{2}$, Grażyna Bukowska ${ }^{1}$ \\ ${ }^{1}$ Uniwersytet Warszawski; \\ ${ }^{2}$ Uniwersytet Ekonomiczny w Poznaniu \\ e-mail: abialek@wne.uw.edu.pl
}

\title{
NIERAPORTOWANA SPRZEDAŻ \\ A LUKA W PODATKU OD WARTOŚCI DODANEJ
}

\section{HIDDEN SALES AND VAT GAP}

DOI: $10.15611 /$ pn.2018.532.26

JEL Classification: H25, H26, H32, K34

Streszczenie: Celem artykułu jest zbadanie zależności pomiędzy nieraportowanymi przychodami ze sprzedaży a wielkością luki w podatku od wartości dodanej z uwzględnieniem uwarunkowań makroekonomicznych i instytucjonalnych. Zweryfikowano hipotezę: im większa luka w podatku od wartości dodanej, tym większa jest skala nieraportowanej przez przedsiębiorców sprzedaży. Wykorzystano dane z badania Business Environment and Enterprise Performance Survey (BEEPS) przeprowadzonego wśród wybranych przedsiębiorstw z państw Europy i Azji. Przeprowadzono analizę regresji (KMNK). Wyniki wskazują m.in. na ujemną zależność pomiędzy wielkością luki w VAT a nieraportowaniem przychodów ze sprzedaży. Wyjaśnieniem może być to, że zaniżanie sprzedaży jest tylko jedną z form uchylania się od VAT, a natura poszczególnych form jest różna. Skala luki podatkowej powstałej w efekcie zaniżenia sprzedaży jest stosunkowo niewielka w porównaniu ze skalą luki podatkowej wynikającej z pozostałych form.

Słowa kluczowe: podatek, luka w VAT, uchylanie się od opodatkowania.

Summary: The aim of the article is to study the relationship between unreported sales and the amount of VAT gap, taking into consideration macroeconomic and institutional environment. The following hypothesis has been verified: the higher the VAT gap, the higher the scale of unreported sales revenue of enterprises. The study is based on the data from Business Environment and Enterprise Performance Survey (BEEPS) conducted among selected enterprises in European and Asian countries. The analysis is based on classical linear regression model (OLS). The results indicate, among others, a negative relationship between the amount of VAT gap and unreported sales revenue. It may results from the fact that hidden sales revenue is just one form of tax evasion, as the nature of particular forms of tax evasion differs. The scale of VAT gap resulting from under-reporting of sales revenue is relatively small, compared to the scale of tax gap resulting from other forms of tax evasion.

Keywords: tax, VAT gap, tax evasion. 


\section{Wstęp}

W większości współczesnych systemów podatkowych występuje podatek obrotowy w formie podatku od wartości dodanej (VAT). W wielu państwach stanowi on główne źródło dochodów władzy publicznej - w przypadku Polski to ponad $40 \%$ wszystkich dochodów ujętych w budżecie państwa [GUS 2017, s. 149]. Luka w podatku od towarów i usług (ptiu), rozumiana jako różnica między potencjalnymi a faktycznymi dochodami z VAT, według szacunków PwC w 2016 r. sięgnęła 52 mld zł (2,9\% PKB Polski). Problem ze ściągalnością tego podatku jest spowodowany m.in. przez szarą strefę, nieuczciwą optymalizację podatkową, niewydolność poboru podatku, oszustwa, upadłość podatników oraz błędy w samowymiarze np. związane ze zróżnicowaniem stawek [PwC 2017].

Szacowana skala luki podatkowej zarówno dla Polski, jak i dla innych państw zmusza do podejmowania działań zmierzających do jej ograniczania. Skuteczne eliminowanie luki wymaga ustalenia przyczyn jej powstawania, a także jej struktury. $\mathrm{Na}$ skalę luki podatkowej w podatku od wartości dodanej wpływa również nierejestrowanie przychodów ze sprzedaży, szczególnie, gdy dotyczy ono sprzedaży detalicznej.

Celem artykułu jest zbadanie zależności pomiędzy nieraportowanymi przychodami ze sprzedaży na poziomie przedsiębiorstwa a wielkością luki w podatku od wartości dodanej z uwzględnieniem jako zmiennych kontrolnych uwarunkowań makroekonomicznych i instytucjonalnych: poziomu bezrobocia, populacji, zaufania do rządu, indeksu korupcji oraz obciążenia podatkowego przedsiębiorstw.

W artykule weryfikacji podlega hipoteza: im większa luka w podatku od wartości dodanej, tym większa jest skala nieraportowanej przez przedsiębiorców sprzedaży. Badanie przeprowadzono, wykorzystując analizę regresji klasyczną metodą najmniejszych kwadratów.

Od 2016 r. polityka Unii Europejskiej została ukierunkowana na zwiększenie ściągalności podatku od wartości dodanej. W szczególności w Polsce od połowy 2016 r. stopniowo wprowadzano system jednolitego pliku kontrolnego, a od 2018 r. obowiązek uzupełniania danych $\mathrm{w}$ tym systemie dotyczy każdego, nawet mikroprzedsiębiorstwa zarejestrowanego jako podatnik VAT. Wymóg ten przyczynił się do ułatwienia kontroli podatników. Oprócz tego wprowadzono obowiązek dokładniejszej weryfikacji danych podmiotów chcących zarejestrować się jako podatnik VAT, obowiązek miesięcznego rozliczania podatku dla nowych podatników, zlikwidowano możliwość kwartalnych rozliczeń dla wszystkich przedsiębiorstw z wyjątkiem małych, przywrócono sankcje podatkowe w przypadku zaniżania zobowiązania podatkowego lub zawyżania podatku do zwrotu bądź do rozliczenia w następnych okresach rozliczeniowych. 


\section{Istota i struktura luki w podatku od wartości dodanej}

Luka w podatku od wartości dodanej powinna być utożsamiana z podejmowaniem nielegalnych działań (uchylanie się od opodatkowania), których celem jest obniżenie zobowiązania lub zawyżenie podatku do zwrotu bądź do rozliczenia w następnych okresach. Przy szacowaniu skali luki nie bierze się pod uwagę czynności, które nie mogą być przedmiotem prawnie skutecznej umowy, np. handlu narkotykami, czy prostytucji, jednak uwzględnia się te czynności, które powinny być opodatkowane zgodnie z obowiązującym prawem, a nie są [Majerová 2016].

Uchylanie się od opodatkowania wywołuje wiele negatywnych konsekwencji. Powoduje ono w szczególności uszczuplenie finansów budżetu państwa, co prowadzi do spowolnienia wzrostu gospodarczego, ponieważ ogranicza możliwości dostarczania dóbr publicznych, inwestycji w infrastrukturę, kapitał ludzki oraz instytucje, które wspierają rynek [Abdixhiku i in. 2017]. Wśród skutków oszustw podatkowych można wymienić także psucie wizerunku danego kraju na arenie międzynarodowej, zaburzenie konkurencji pomiędzy przedsiębiorstwami w danym sektorze [Leoński 2013], możliwość prania brudnych pieniędzy, finansowanie i przyzwolenie na przestępczość, negatywny wpływ na uczciwe przedsiębiorstwa oraz negatywne działania organów podatkowych [PwC 2017].

Wobec luki podatkowej władza publiczna nie może pozostać bierna. W literaturze (np. [Kudła 2004; Bernal 2008]) można znaleźć wskazówki, jak ograniczyć skalę uchylania się od opodatkowania. Walka z luką w podatku od wartości dodanej wymaga jednak szczegółowej wiedzy dotyczącej tego, jak ona powstaje i co się na nią składa.

Lukę podatkową można oszacować metodami pośrednimi (podejście odgórne). Są one głównie stosowane w krajach rozwijających się i bazują na wskaźnikach makroekonomicznych pochodzących np. z rachunków narodowych i finansowych. Polegają one na obliczaniu różnicy pomiędzy kwotą podatków, które powinny wpłynąc do budżetu państwa, a rzeczywistymi wpływami. Metoda ta pozwala zobaczyć rozmiar uchylania się od opodatkowania przez obywateli, jednak nie daje aż takich możliwości analiz ekonomicznych, jak podejście oddolne. Dane makro nie pozwalają na ocenę powodu powstania luki w podatku, pojawia się także problem z wiarygodnością danych oraz oceną możliwości legalnego uchylania się od opodatkowania. Analiza na poziomie mikro pozwala poprawić administrację podatkową i system podatkowy, ponieważ dostarcza informacji np. odnośnie do indywidualnych komponentów luki z podziałem na grupy podatników takie jak osoby fizyczne, przedsiębiorstwa, kategorie dochodu, sektor działalności oraz rodzaj oszustwa [Klonowska 2017, s. 53-60]. W przypadku pomiaru luki w podatku w skali makro stosowanych jest kilka metod, które biorą pod uwagę różne wskaźniki makroekonomiczne [Rubin 2011].

Luka w podatku od wartości dodanej nie ma jednorodnego charakteru i może być efektem różnych zdarzeń. Przykładowa klasyfikacja form uchylania się od po- 
datku od wartości dodanej została przedstawiona na rys. 1. Wśród form uchylania się od podatku można wymienić: znikanie podatnika po sprzedaży towaru z nieuregulowanym podatkiem od towarów i usług, użycie zerowej stawki podatku w przypadku imitowanej wewnątrzwspólnotowej dostawy towarów, wykazywanie zakupu towaru przy wyższej stawce podatku niż faktyczna, sprzedaż zestawu towarów i usług, które opodatkowane są różnymi stawkami i zaniżanie ceny tej części, dla której stawka jest najwyższa (por. [Pastuszka 2016]). Za inną formę uchylania się od opodatkowania można uznać zaniżanie wartości sprzedaży.

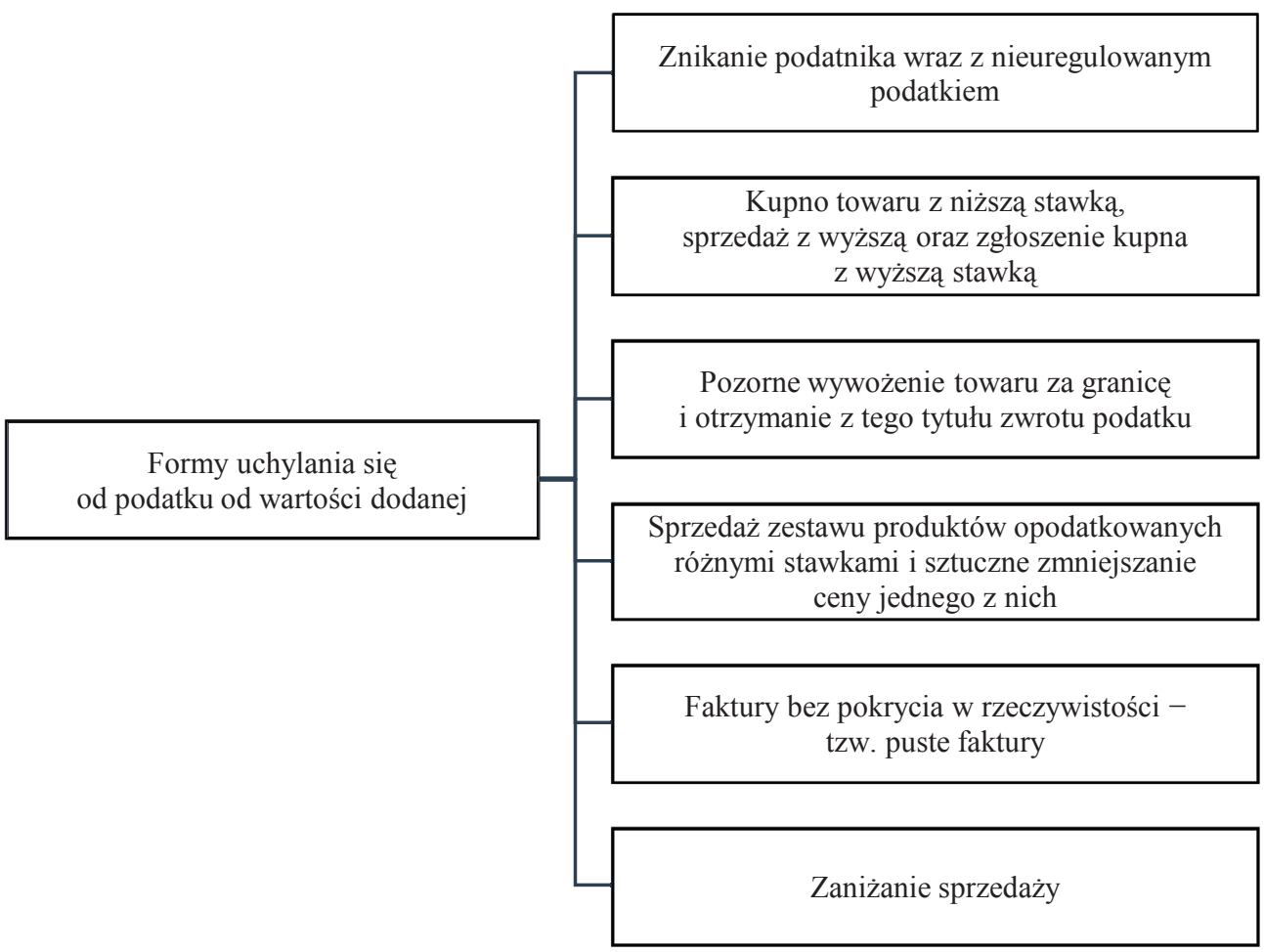

Rys. 1. Formy uchylania się od podatku od wartości dodanej

Źródło: opracowanie własne na podstawie [Tratkiewicz 2016].

$\mathrm{W}$ nieco innym ujęciu, choć zasadniczo zbieżnym z rys. 1, strukturę luki w podatku od wartości dodanej prezentują G. Poniatowski i in. [2016, s. 27]. Tabela 1 przedstawia dekompozycję tej luki dla Polski w latach 2009-2013.

Z tabeli 1 wynika, że spośród elementów luki w VAT w Polsce w 2013 r. najistotniejsza była pozycja „Pozostałe” (41\%). Świadczy to o tym, że istotna część luki w podatku od wartości dodanej jest trudna do wyeliminowania, ponieważ tworzą ją komponenty będące konsekwencją konkurencji rynkowej, cyklu koniunkturalnego, 
Tabela 1. Dekompozycja luki w podatku od wartości dodanej dla Polski (w mln PLN)

\begin{tabular}{|c|c|c|c|c|c|c|}
\hline Rok & $\begin{array}{c}\text { Przestępstwa } \\
\text { MTIC }^{*}\end{array}$ & $\begin{array}{c}\text { Przemyt }- \\
\text { wyroby } \\
\text { akcyzowe }\end{array}$ & $\begin{array}{c}\text { Zawyżanie } \\
\text { podatku } \\
\text { naliczonego }\end{array}$ & $\begin{array}{c}\text { Nadużycie } \\
\text { zwolnienia } \\
\text { podmiotowego }\end{array}$ & Pomyłki & Pozostałe \\
\hline 2009 & 3400 & 1640 & 3840 & - & 2660 & - \\
\hline 2010 & 3390 & 1690 & 2310 & - & 2800 & - \\
\hline 2011 & 4530 & 2110 & 8180 & 530 & 3030 & 9790 \\
\hline 2012 & 4440 & 2690 & 12110 & 820 & 3180 & 16060 \\
\hline 2013 & 4520 & 2680 & 13540 & 1130 & 3240 & 17420 \\
\hline
\end{tabular}

${ }^{*}$ Missing trader intra community (MTIC) - G. Poniatowski i in. [2016, s. 21] definiują je jako „systematyczne i zorganizowane wykorzystywanie systemu VAT do nielegalnego czerpania dochodów", przykładowo w formie tzw. karuzeli podatkowej.

Źródło: [Poniatowski i in. 2016, s. 27].

rozwoju technologicznego i błędów w zarządzaniu [Poniatowski i in. 2016, s. 28]. Zawyżanie zwrotów odpowiadało za 32\% luki podatkowej, przestępstwa typu MTIC za $11 \%$, pomyłki formalne i rachunkowe za $7 \%$, a nadużycia zwolnienia podmiotowego za $3 \%$.

\section{Nieraportowana sprzedaż jako element luki w VAT}

Jak już wskazano, nieraportowanie sprzedaży jest przejawem nielegalnego uchylania się od opodatkowania i zarazem jednym z elementów tworzących lukę w podatku od wartości dodanej. Problem nieraportowania sprzedaży dotyczy różnych podmiotów. Można go rozpatrywać, uwzględniając zarówno skalę ich działalności (przedsiębiorcy spełniający i niespełniający kryterium podmiotowego zwolnienia z VAT), jak i rodzaj sprzedaży (segment sprzedaży detalicznej B2C versus segment sprzedaży hurtowej B2B).

W odniesieniu do skali działalności należy zauważyć, że nieraportowanie sprzedaży może się wiązać z nadużywaniem zwolnienia podmiotowego z VAT. W Polsce jest ono przewidziane dla podmiotów, których wartość przychodów ze sprzedaży opodatkowanej nie przekroczyła łącznie w poprzednim roku podatkowym kwoty 200000 zł. Podatnikom przekraczającym ustawowy limit może zależeć na zaniżeniu wartości sprzedaży w celu wykazania uprawnienia do zwolnienia. Nadużywanie zwolnienia podmiotowego może dotyczyć stosunkowo niewielkich kwot, jednakże w skali całej gospodarki przyczynia się ono do widocznego ubytku wpływów z VAT [Poniatowski i in. 2016, s. 24].

Biorąc pod uwagę rodzaj segmentu sprzedaży, można przyjąć, że problem nieraportowania sprzedaży dominuje w obrocie detalicznym, w którym konsument jest finalnym odbiorcą. W praktyce realizowane jest to poprzez niewystawienie paragonu, względnie rozliczanie w kwocie netto zamiast wystawienia faktury VAT. Mecha- 
nizm podatku od wartości dodanej, który zakłada odliczenie podatku naliczonego przy zakupie od podatku należnego ze sprzedaży, gwarantuje przedsiębiorcy, że ten nie poniesie jego ciężaru w sensie ekonomicznym, a jedynie odprowadzi na rzecz administracji skarbowej podatek otrzymany z różnicy. Wysokość korzyści, która powstaje dla sprzedawcy w sytuacji sprzedaży bez paragonu lub faktury, zależy od tego, po jakiej cenie zdecyduje się on dokonać sprzedaży ${ }^{1}$. Sprzedaż po cenie odpowiadającej cenie netto gwarantuje mu uzyskanie przewidzianej marży. Sprzedaż po cenie wyższej, na przykład odpowiadającej cenie brutto, powoduje, że poza „zwykłą" korzyścią w postaci marży przedsiębiorca przechwytuje wartość należnego VAT.

Podobny mechanizm uwidocznia się w obrocie B2B, gdy w dostawach między przedsiębiorcami będącymi podatnikami VAT odbiorca wyprowadza towar z ewidencjonowanego obrotu gospodarczego do szarej strefy. Występuje on wówczas w charakterze finalnego konsumenta, domagając się od dostawcy wystawienia paragonu zamiast faktury VAT. Dostawca raportuje sprzedaż i wykazuje ją dla celów podatku dochodowego. Tym samym jest on ostatnim ogniwem legalnego obrotu ${ }^{2}$. Natomiast w przypadku odbiorcy następuje anonimizacja zakupu i wyprowadzenie towaru z rejestrowanego obrotu przedsiębiorczego, mimo że de facto znajduje się on w nim w dalszym ciągu. Co prawda nierejestrowany zakup nie generuje u odbiorcy kosztów uzyskania przychodu, jednak w przypadku dalszej odsprzedaży nie powstanie u niego również przychód do opodatkowania i podatnik ten nie zapłaci podatku dochodowego. Na tym etapie towar trafia od razu do finalnego odbiorcy lub krąży dalej w obiegu nierejestrowanym pomiędzy przedsiębiorcami. Jeżeli przedsiębiorcy dokonują między sobą nierejestrowanych podatkowo dostaw po cenie wyższej od ceny netto legalnych odpowiedników, są w stanie zagwarantować sobie marżę i przechwycić część należnego VAT, który w tej sytuacji powinien wystąpić.

Powyższy przykład zakłada, że do jakiegoś etapu towar generuje wpływy z podatku od towarów i usług i podatku dochodowego. W ostrzejszej formie problem może wystąpić w przypadku, gdy towar od początku obiegu gospodarczego znajduje się poza ewidencją. Naturalnie narażone są na to towary nieprzetworzone, na przykład kruszywa od momentu ich wydobycia. W każdej jednak sytuacji obniżenie ceny i niepłacenie podatków powodują zachwianie mechanizmu konkurencji rynkowej i mogą prowadzić do zmniejszenia sprzedaży i w konsekwencji trudności finansowych u podmiotów, które nie uchylają się od podatków.

Jak wskazuje A. Bernal [2008, s. 48], uchylanie się od jednego podatku (w tym przypadku podatku od wartości dodanej) może współwystępować z uchylaniem się od podatków dochodowych (w zależności od formy prawnej przedsiębiorcy: podat-

${ }^{1} \mathrm{~W}$ poniższej analizie abstrahuje się od ryzyka podatkowego, jakie ponoszą podatnicy w związku $\mathrm{z}$ tego typu działaniami.

2 Jest to obrót legalny w sensie formalnym. Z drugiej strony może on budzić wątpliwości z perspektywy moralności podatkowej, jeśli sprzedający ma świadomość, że realizuje sprzedaż dla przedsiębiorcy. 
kiem dochodowym od osób prawnych względnie podatkiem dochodowym od osób fizycznych). W analizowanych powyżej przypadkach przychodem w rozumieniu podatku dochodowego powinna być kwota należnego sprzedawcy przychodu pomniejszona o należny podatek od towarów i usług. Ponieważ nie raportuje on sprzedaży, nie zostanie ona objęta podatkiem dochodowym i dojdzie do redukcji podstawy opodatkowania $\mathrm{w}$ tym podatku ${ }^{3}$. Działanie takie naraża państwo ${ }^{4}$ na ubytek wpływów zarówno z podatku od towarów i usług jak i podatku dochodowego ${ }^{5}$.

Jak wykazano w poprzedniej części artykułu, nieraportowana sprzedaż stanowi jeden z elementów luki w VAT. W badaniu prezentowanym w niniejszym artykule podjęto próbę uchwycenia związku między nieraportowaną sprzedażą a luką w VAT. Takie podejście jest możliwe, po pierwsze, dlatego, że nieraportowana sprzedaż odpowiada jedynie za bardzo niewielki odsetek luki w VAT, wynoszący niespełna 3\%. Dekompozycja luki wskazuje, że zdecydowanie większe znaczenie mają m.in. zawyżanie VAT naliczonego w postaci odliczania przez przedsiębiorcę dóbr wykorzystywanych w celach prywatnych i wystawiania „lewych faktur” czy też oszustwa określane mianem karuzeli VAT [Poniatowski i in. 2016, s. 23 i nast.].

Po drugie, wskazane w tab. 1 nadużycie zwolnienia podmiotowego jest tylko jedną z sytuacji, w której przedsiębiorcy nie raportują sprzedaży. Taka sytuacja z pewnością nie jest jedyną. Niewykazywanie sprzedaży nie dotyczy wyłącznie podmiotów stosunkowo małych, które w niedużym stopniu przekraczają limit zwolnienia podmiotowego. Jak wskazano powyżej, nieraportowanie sprzedaży występuje u podmiotów niezależnie od ich wielkości, w sprzedaży zarówno detalicznej, jak i w obrocie B2B.

Po trzecie, wykorzystana w badaniu zmienna Hidden sales została zaczerpnięta $\mathrm{z}$ badania ankietowego przeprowadzonego na ograniczonej grupie podmiotów w grupie państw objętych badaniem. Nie można przy tym pomijać możliwego błędu

${ }^{3}$ W najczęściej spotykanych przypadkach punktów sprzedaży detalicznej prowadzonych przez mikroprzedsiębiorców zachodzi konieczność rozchodowania towaru sprzedanego bez podatku od towarów i usług. Możliwe jest to na przykład w drodze zaewidencjonowania sprzedaży po minimalnej marży, przy uzyskaniu dodatkowej korzyści z odroczenia płatności VAT-u.

${ }^{4}$ W celu zwalczania tego typu działań administracje wielu państw decydują się na takie kroki, jak wprowadzenie wymogu posiadania paragonu czy tzw. loterie paragonowe, które mają stanowić dla konsumentów zachętę do domagania się wystawiania paragonu.

${ }^{5}$ Związków pomiędzy podatkiem od wartości dodanej a podatkiem dochodowym jest więcej. Poza wpływem na stronę przychodową, VAT może niekiedy wykazywać charakter kosztotwórczy i w ten sposób również oddziaływać na wysokość podstawy opodatkowania podatkiem dochodowym. Dzieje się tak m.in. wówczas, gdy podatnik z określonych powodów nie może odliczyć (w całości lub części) VAT naliczonego we wcześniejszych fazach obrotu - na przykład gdy ustawodawca ogranicza możliwość odliczenia VAT naliczonego w stosunku do określonych kategorii towarów i usług lub gdy zwolnienia z VAT są wprowadzone na poziomie innym niż sprzedaż na rzecz ostatecznego konsumenta (por. [Litwińczuk i in. 2013, s. 482, 483]). Szczegółowe omówienie tego typu sytuacji wykracza poza ramy artykułu. 
pomiaru, którego źródłem jest badanie ankietowe. Jak wskazuje A. Klonowska [2017, s. 56-60], występują wówczas problemy z doborem próby oraz brakiem prawdomówności wśród ankietowanych. Szczególnie w społeczeństwie, w którym niepłacenie podatków jest piętnowane lub kary są wysokie, zachodzi wysokie prawdopodobieństwo zaniżania skali oszustw podatkowych. Dodatkowo dane z ankiet skupiają się na analizie czynników psychologicznych i socjologicznych, a nie ekonomicznych. Powyższe czynniki powodują, że wykorzystanej w badaniu zmiennej nie można jednoznacznie utożsamiać z nieraportowaną sprzedażą oszacowaną na potrzeby ustalenia luki w VAT.

\section{Definicje zmiennych i forma modelu}

W analizie wykorzystano dane z badania Business Environment and Enterprise Performance Survey (BEEPS) przeprowadzonego wśród przedsiębiorstw z różnych państw w 2005 r.. L. Abdixhiku i in. [2017] również wykorzystali dane BEEPS. Wyjątkami były Polska i Mołdawia, gdzie badanie to zostało przeprowadzone w 2003 r. Ponieważ w artykule modelowane są dane przekrojowe, struktura czasowa dla tych dwóch krajów może istotnie wpływać na wyniki badania, szczególnie że Polska oraz inne kraje, które wzięły udział w badaniu, w 2004 r. wstąpiły do Unii Europejskiej, natomiast Mołdawia w tym czasie dostosowywała prawo do dyrektyw i prawodawstwa Unii Europejskiej [Sikora-Gaca 2013, s. 108-116]. Z tego względu wyłączono je z badania.

Analiza objęła dane przedsiębiorstw z: Bułgarii, Albanii, Chorwacji, Białorusi, Gruzji, Tadżykistanu, Turcji, Ukrainy, Uzbekistanu, Rosji, Rumunii, Kazachstanu, Bośni i Hercegowiny, Azerbejdżanu, FYR Macedonii, Armenii, Kirgistanu, Estonii, Czech, Węgier, Łotwy, Litwy, Słowacji, Słowenii, Hiszpanii, Irlandii oraz Serbii i Czarnogóry (którym to państwom przypisano zmienne binarne).

Uwzględniono dane makroekonomiczne dotyczące bezrobocia, aparatu państwowego, luki w VAT w 2005 r., zaczerpnięte z opracowania Komisji Europejskiej [European Commission 2013], Indeksu Percepcji Korupcji CPI na podstawie rankingu wykonanego przez Transparency International oraz wielkości populacji. Dane dotyczące bezrobocia i całkowitej populacji pochodzą z bazy danych Banku Światowego. Otoczenie instytucjonalne, w jakim działa przedsiębiorstwo, także ma duże znaczenie. W literaturze wykazano ujemną zależność między korupcją a przedsiębiorczością - im mniejsza korupcja, tym większa przedsiębiorczość, a więc też rozwój gospodarczy [Pluskota 2018]. Opis zmiennych wykorzystanych w modelu regresji oszacowanym metodą najmniejszych kwadratów (MNK) przedstawiono w tab. 2.

Wyższe koszty dostosowań Compliance_cost i wyższe stopy podatkowe Tax_ Rate mogą zachęcać do uchylania się od opodatkowania sprzedaży, natomiast zaufa- 
Tabela 2. Opis zmiennych użytych w modelu regresji liniowej

\begin{tabular}{|c|c|c|}
\hline Zmienna & Źródło & Opis \\
\hline Hidden_sales & BEEPS & $\begin{array}{l}\text { uchylanie się od dokumentowania sprzedaży w \% wielkości } \\
\text { ukrytej sprzedaży, zawiera tzw. szarą strefę }\end{array}$ \\
\hline $\begin{array}{l}\text { Trust_in_ } \\
\text { government }\end{array}$ & BEEPS & $\begin{array}{l}\text { zaufanie do rządu, łatwość uzyskania od administracji } \\
\text { państwowej ważnych dla firmy informacji dotyczących prawa } \\
\text { i regulacji; przybiera wartości od } 1 \text { (brak) do } 6 \text { (wysokie) }\end{array}$ \\
\hline $\begin{array}{l}\text { Compliance_ } \\
\text { cost }\end{array}$ & BEEPS & $\begin{array}{l}\text { koszty dostosowań - czas spędzony przez zarząd na } \\
\text { rozwiązywanie problemów związanych z radzeniem sobie } \\
\text { z wymaganiami prawnymi (w \%) }\end{array}$ \\
\hline Corruption & BEEPS & $\begin{array}{l}\text { wskaźnik korupcji - informacja na temat dodatkowych płatności/ } \\
\text { prezentów potrzebnych do załatwienia sprawy w urzędzie; } \\
\text { przyjmuje wartości od } 1 \text { (brak) do } 6 \text { (wysoka) }\end{array}$ \\
\hline Tax_Rate & BEEPS & $\begin{array}{l}\text { stopa podatkowa - miara obciążenia podatkowego postrzegana } \\
\text { przez firmę; przybiera wartości od } 1 \text { (niskie) do } 4 \text { (wysokie) }\end{array}$ \\
\hline sector & BEEPS & $\begin{array}{l}\text { zmienne binarne dla branż: Górnictwo i kopalnictwo, } \\
\text { Budownictwo, Produkcja, Transport i komunikacja, Sprzedaż } \\
\text { hurtowa i detaliczna, naprawy, Nieruchomości, wynajem i usługi } \\
\text { biznesowe, Hotele i restauracje, Pozostałe }\end{array}$ \\
\hline size & BEEPS & $\begin{array}{l}\text { wielkość przedsiębiorstwa - zmienna binarna, która przyjmuje } \\
\text { wartość } 1 \text { dla średniej/dużej firmy, a } 0 \text { w przeciwnym przypadku }\end{array}$ \\
\hline city & BEEPS & $\begin{array}{l}\text { zmienne binarne przyjmujące wartość } 1 \text {, gdy firma ma siedzibę } \\
\text { w mieście o danej wielkości, a } 0 \mathrm{w} \text { przeciwnym przypadku, przy } \\
\text { czym im większy numer przy zmiennej, tym mniejsze miasto }\end{array}$ \\
\hline country & BEEPS & zmienne binarne dla krajów objętych badaniem \\
\hline VAT_GAP & $\begin{array}{l}\text { [European } \\
\text { Commission } \\
\text { 2013] }\end{array}$ & $\begin{array}{l}\text { ln(luka w VAT wyrażona w euro) nie zawiera działalności } \\
\text { nielegalnej, tzw. szarej strefy }\end{array}$ \\
\hline$C P I$ & $\begin{array}{l}\text { Transparency } \\
\text { International }\end{array}$ & $\begin{array}{l}\text { Indeks Percepcji Korupcji - zmienna przyjmująca wartości } \\
\text { od } 0 \text { (kraj bardzo skorumpowany) do 10, gdy brak korupcji }\end{array}$ \\
\hline unemployment & World Bank & wielkość bezrobocia jako \% całkowitej siły roboczej w kraju \\
\hline total_population & World Bank & $\ln$ (całkowita populacja) \\
\hline
\end{tabular}

Źródło: opracowanie własne.

nie do rządu i jasne przepisy powinny zniechęcać do uchylania się od opodatkowania [Abdixhiku i in. 2017]. Spodziewano się, że większa skłonność do uchylania się od dokumentowania sprzedaży występuje tam, gdzie wykonywanych jest więcej operacji gotówkowych oraz że większe przedsiębiorstwa są bardziej niechętne do uchylania się od dokumentowania sprzedaży. I. Majerová [2016] wykazała, że w warunkach niższej korupcji występuje mniejsza luka w VAT i takiej zależności spodziewano się $\mathrm{w}$ odniesieniu do dokumentowania sprzedaży. Większe miasto oraz większa populacja również mogą sprzyjać większej luce w dokumentowaniu sprzedaży, ponieważ 
trudniej wtedy skontrolować każdą firmę, a ludzie czują się wtedy bardziej anonimowi. Z kolei wyższy poziom bezrobocia może generować większy poziom uchylania się od dokumentowania sprzedaży, ponieważ osoba bez pracy może nie być tak chętna do uiszczania dodatkowych opłat. Z drugiej strony nie ma ona tak dużej możliwości, żeby oszukiwać państwo w płaceniu podatków, więc wpływ tej zmiennej na poziom unikania dokumentowania sprzedaży nie jest oczywisty.

\section{Wyniki}

W celu zweryfikowania zależności pomiędzy zmiennymi przedstawionymi w tabeli 1 wykorzystano model liniowy z dwoma zmiennymi zlogarytmowanymi. Początkowo w regresji zostały użyte wszystkie poziomy dotyczące sektorów, miast i krajów poza poziomami bazowymi, jednak większość z nich została pominięta w ostatecznym modelu ze względu na ich współliniowość, łączną nieistotność (zgodnie z teorią pominięcie zmiennych nieistotnych statystycznie działa korzystnie na jakość oszacowań parametrów zmiennych istotnych) oraz poprawę wyniku testu RESET. Wyniki regresji, po przeprowadzeniu testów diagnostycznych, przedstawia tabela 3. Oszacowany model regresji przyjął następującą postać:

Hidden sales $=\beta_{1}$ Trust_in_government $+\beta_{2}$ Compliance_cost $+\beta_{3} C P I+$

$\beta_{4}$ Corruption $+\beta_{5}$ Tax_Rate $+\beta_{6}$ VAT_GAP $+\beta_{7}$ sector $_{i}+$

$\beta_{8}$ size $_{j}+\beta_{9}$ city $_{t}+\beta_{10}$ country $+\beta_{11}$ unemployment +

$\beta_{12}$ total_population + const.

Wyniki badania wskazują, że w państwach o wysokiej populacji i wysokim bezrobociu, w których zaufanie do rządu jest duże, a korupcja (mierzona zarówno indeksem percepcji korupcji CPI (przyjmuje niższe wartości przy wyższej korupcji), jak i wskaźnikiem korupcji) niższa, występuje niższy udział sprzedaży nierejestrowanej.

W przedsiębiorstwach, w których ilość czasu spędzona przez podatników na wywiązywanie się z obowiązków podatkowych, a także w tych, w których stawki podatkowe są postrzegane jako wysokie, wzrasta udział sprzedaży nierejestrowanej rośnie. Skala ukrytych przychodów jest mniejsza w dużych i średnich przedsiębiorstwach, które prowadzą działalność w dużych miastach liczących 250 tys. $-1 \mathrm{mln}$ mieszkańców. Odwrotna sytuacja ma miejsce w przedsiębiorstwach z branży budowlanej, hotelarskiej i gastronomicznej.

Z perspektywy postawionej hipotezy szczególnie ważna jest nieoczekiwana, ujemna zależność między wielkością luki w podatku od wartości dodanej a zaniżaniem przychodów ze sprzedaży. Wyjaśnieniem tej ujemnej zależności może być to, że zaniżanie przychodów ze sprzedaży jest tylko jedną z form uchylania się od podatku od wartości dodanej, a natura poszczególnych form jest różna. Dodatkowo można również wyciągnąć wniosek, że skala luki podatkowej powstałej w efekcie 
Tabela 3. Determinanty nieujawniania przychodów ze sprzedaży

\begin{tabular}{|c|c|c|}
\hline \multirow{2}{*}{$\begin{array}{r}\text { Zmienna } \\
\text { Trust_in_government }\end{array}$} & \multicolumn{2}{|c|}{ Hidden_sales } \\
\hline & $-0,231$ & $* *$ \\
\hline & $(0,105)$ & \\
\hline \multirow[t]{2}{*}{ Compliance_cost } & 0,105 & $* *$ \\
\hline & $(0,042)$ & \\
\hline \multirow[t]{2}{*}{ CPI } & $-2,120$ & $* * *$ \\
\hline & $(0,235)$ & \\
\hline \multirow[t]{2}{*}{ Corruption } & 0,133 & $* *$ \\
\hline & $(0,055)$ & \\
\hline \multirow[t]{2}{*}{ Tax_Rate } & 0,754 & $* * *$ \\
\hline & $(0,122)$ & \\
\hline \multirow[t]{2}{*}{ In_VAT_GAP } & $-1,323$ & $* * *$ \\
\hline & $(0,399)$ & \\
\hline Sector Dummies & YES & \\
\hline \multirow[t]{2}{*}{ Construction } & 1,264 & $*$ \\
\hline & $(0,727)$ & \\
\hline \multirow[t]{2}{*}{ Hotels \& Restaurants } & 3,631 & $* * *$ \\
\hline & $(1,055)$ & \\
\hline \multirow[t]{2}{*}{ medium_size } & $-3,122$ & $* * *$ \\
\hline & $(0,610)$ & \\
\hline \multirow[t]{2}{*}{ large_size } & $-4,734$ & $* * *$ \\
\hline & $(0,665)$ & \\
\hline \multirow[t]{2}{*}{ City dummies for $250000-1 \mathrm{mln}$ people } & $-2,318$ & $* * *$ \\
\hline & $(0,789)$ & \\
\hline Country Dummies & YES & \\
\hline \multirow[t]{2}{*}{ unemployment } & $-0,267$ & $* * *$ \\
\hline & $(0,104)$ & \\
\hline \multirow[t]{2}{*}{ total_population } & $-0,629$ & $* *$ \\
\hline & $(0,256)$ & \\
\hline \multirow[t]{2}{*}{ const } & 57,636 & $* * *$ \\
\hline & $(9,823)$ & \\
\hline
\end{tabular}

$R^{2}=0,061$; zmienna istotna na poziomie $1 \%(* * *), 5 \%(* *), 10 \%\left(^{*}\right)$.

Błędy standardowe w nawiasach.

Źródło: opracowanie własne.

zaniżenia sprzedaży jest stosunkowo niewielka w porównaniu ze skalą luki podatkowej wynikającej z pozostałych form. Istotne znaczenie w wyjaśnianiu ujemnej zależności ma fakt, że w wypadku pozostałych form uchylania się od podatku od wartości dodanej podatnicy osiągają korzyści, zawyżając wartość przychodów ze 
sprzedaży. Taka sytuacja występuje w szczególności wówczas, gdy wyłudzający podatek wystawiają tzw. puste faktury, gdy dokonują fikcyjnego wywozu towarów za granicę, a także wówczas, gdy zawyżają wartość obrotu w ramach tzw. karuzel podatkowych.

\section{Zakończenie}

Wyniki przeprowadzonego badania wskazują na zróżnicowanie form uchylania się od podatku od wartości dodanej. Luka w tym podatku powstaje m.in. w efekcie zaniżania przychodów ze sprzedaży. Zaniżanie przychodów ze sprzedaży może wynikać z różnych pobudek. Ważną przyczyną nieraportowania sprzedaży może być chęć osiągnięcia korzyści w podatkach dochodowych.

Ze względu na to, że natura poszczególnych form uchylania się od podatku od wartości dodanej jest różna, działania podejmowane przez władzę publiczną zmierzające do ograniczenia tego zjawiska powinny być dostosowane do tych form. Wskazówki dotyczące tego, jak ograniczyć zaniżanie przychodów ze sprzedaży, można znaleźć w przedstawionym modelu. Władza publiczna, wiedząc, że na skalę nierejestrowanej sprzedaży wpływa w szczególności poziom korupcji, wysokość podatków, czy koszty wywiązywania się z obowiązków podatkowych, może wpływać na wysokość tych parametrów. $Z$ drugiej strony, jeśli wiadomo, że określone sektory gospodarki są dotknięte problemem bardziej niż inne, to uwaga administracji skarbowej powinna być skierowana właśnie w tę stronę.

Problem luki w podatku od wartości dodanej ze względu na skalę zjawiska ma istotne znaczenie zarówno dla władzy publicznej, jak i dla podatników. Opisany w artykule wątek stanowi wyłącznie wierzchołek góry lodowej. Prowadzenie dalszych badań w tym obszarze jest niezbędne.

\section{Literatura}

Abdixhiku L., Krasniqi B., Pugh G., Hashi I., 2017, Firm-level determinants of tax evasion in transition economies, Economic System, no. 41, s. 354-366.

Bernal A., 2008, Zjawisko uchylania się od podatków dochodowych i metody jego ograniczania, Difin, Warszawa.

European Commission, 2013, Study to quantify and analyse the VAT Gap in the EU-27 Member States. Final Report, https://ec.europa.eu/taxation_customs/sites/taxation/files/docs/body/vat-gap.pdf.

GUS, 2017, Sytuacja makroekonomiczna w Polsce na tle procesów w gospodarce światowej w 2016 roku, Główny Urząd Statystyczny, Warszawa.

Klonowska A., 2017, Luka podatkowa. Skutki dla finansów publicznych, C.H. Beck, Warszawa.

Kudła J., 2004, Ekonomiczne problemy kosztów opodatkowania i nielegalnego unikania podatków, Wydawnictwo Nowy Dziennik, Warszawa.

Leoński W., 2013, Zjawisko uchylania się od opodatkowania w grupach społeczno-zawodowych, Zeszyty Naukowe Wydziału Nauk Ekonomicznych, nr 17, s. 157-167. 
Litwińczuk H., Karwat P., Pietrasiewicz W., Tetłak K., Kaznowski A., 2013, Prawo podatkowe przedsiębiorców, Wolters Kluwer, Warszawa.

Majerová I., 2016, The impact of some variables on the VAT gap in the member states of the European Union company, Quarterly Journal Oeconomia Copernicana, nr 7, s. 339-355.

Pastuszka J., 2016, Planowane rozwiazania ograniczajace lukę podatkowa VAT w Polsce. Nowe metody wykrywania nieprawidłowości i ich eliminacji, Kontrola Państwowa, nr 4 (369), s. 102-119.

Pluskota A., 2018, Wpływ korupcji na przedsiębiorczość, Acta Universitatis Lodziensis. Folia Oeconomica, $\mathrm{nr}$ (2) 334, s. 201-212.

Poniatowski G., Neneman J., Michalik T., 2016, VAT non-compliance in Poland under scrutiny. Problem nieściagalności Vat w Polsce pod lupa, mBank - CASE Seminar Proceedings No. 142/2016, Zeszyty mBank - CASE Nr 142/2016.

PwC, 2017, Wytudzenia VAT - luka podatkowa w 2016 r. i prognoza na 2017 r., materiały z konferencji prasowej 19.10.2017, https://www.pwc.pl/pl/media/2017/2017-10-19-pwc-luka-VAT-2017.html (8.01.2018).

Rubin M., 2011, The practicality of the top-down approach to estimating the direct tax gap, HRMC Working Paper, no. 12, s. 109-127.

Sikora-Gaca M., 2013, System partyjny Mołdawii w latach 1989-2009, Wydawnictwo Tako, Toruń.

Tratkiewicz T., 2016, Luka w VAT - sposoby przeciwdziałania w Polsce i Unii Europejskiej, Zeszyty Naukowe Uniwersytetu Ekonomicznego w Katowicach, nr 294, s. 185-196. 